\title{
Evaluation of Molecular Methods to Identify Counterfeits With Soy in Different Meat Products
}

\author{
Oana REGET, Alexandra TĂBĂRAN*, Sorin Daniel DAN, Ionuț CORDIŞ, Dana Liana PUSTA, \\ Marian MIHAIU \\ Faculty of Veterinary Medicine, University of Agricultural Sciences and Veterinary Medicine, Mănăştur \\ Street, no.3/5, Cluj-Napoca, Romania \\ Corresponding author: lapusan_alexandra@yahoo.com
}

Bulletin UASVM Veterinary Medicine 72(1) / 2015,

Print ISSN 1843-5270; Electronic ISSN 1843-5378

DOI:10.15835/buasvmcn-vm: 11097

\begin{abstract}
Soybean proteins are vegetal sources used currently in the meat product industry in order to increase the nutritional composition and to obtain products with characteristic sensorial properties. Due to the lower price compared to the animal origin proteins, these soybean extracts are frequently used as additives and not mentioned on the product's label. The aim of this study was to evaluate the presence of the soybean DNA in meat products marketed on the regional area studied. Also, we wanted to assess if the soybean adding was genetically modified organism. The material chosen for this study was represented by 82 meat product samples, marleted on a regional area. The technique chosen for the DNA identification was the polymerase chain reaction (PCR) with specific primers for soybean lectin protein (LEC1) and EPSPS-B1 gene for genetically modified soybean. Our study showed that from the total amount of samples examined $6.09 \%(\mathrm{n}=5)$ were found positive for soybean DNA, without being mentioned on the product's label. No sample was found positive for genetically modified soybean protein adding in the meat products examined. We concluded that there is a relatively high risk of forgeries by soy protein adding in the meat products marketed in the regional area investigated. We recommend the further testing of meat products by the competent authorities in order to identify through standardize methods the genetically modified soybean presence.
\end{abstract}

Keywords: DNA, genetically modified soybean.

\section{INTRODUCTION}

The use of soybean proteins as meat extenders has spread significantly due to the interesting nutritional and functional properties that are present in soybean proteins.

Together with these properties, health and economical reasons are the major causes for the addition of soybean proteins to meat products. Nevertheless, despite the good properties associated to soybean proteins, there are many countries in which the addition of these proteins is forbidden or in which the addition of soybean proteins is allowed up to a certain extent. The consumption of meat products containing soy proteins fraudulently can trigger allergic reactions in some individuals (Savage et al., 2010). Thus, the need of analytical methods enabling the detection of added soybean proteins in meat products is obvious.

Microscopic, electrophoretic, immunologic, and chromatographic methods are the most widely used for this purpose (Belloque et al., 2002). PCR-based detection of allergens has become increasingly popular. A major advantage in the employment of PCR-based methods lies in the high specificity of the reaction. Additionally, proteins in foods that have been harshly processed, might not be detectable in the classical ELISA based approach for example, while the target DNA might be nevertheless efficiently extracted under such denaturing conditions. Another advantage that the PCR holds out against the classical protein- 
based analytical methods is its stability against the backdrop of geographical and seasonal variations in fruits and nuts for example, with accompanying variance in protein composition (Poms et al., 2007).

Genetically modified foods are often in the news. While genetic modifications have made improvements in many crops and helped to increase yields. Much of the world, in contrast, has experienced strong and increasing resistance to the introduction of any genetically modified foods to the market place (Brandner, 2002). Most of the developed analytical methods for GMO detection are DNA-based, since protein-based assays are not suitable for processed food. Polymerase chain reaction (PCR) and real time PCR-based methods have been generally accepted for regulatory compliance. (Rodriguez-Lazaro et al., 2007). Therefore, the aim of this study was to estimate the adulteration degree of meat products with soybean protein in a regional market. Also, we assessed the accuracy of meat products labeling in the samples. The samples that tested positive were also investigated for possible genetically modified soybean protein adding.

\section{MATERIALS AND METHODS}

The material that was used for this study was represented by 82 meat product samples from the following sorts: 20 minced meat samples (beef and pork meat or beef and sheep meat), 22 samples of baloney and 40 samples of sausages. All of the samples were labeled also with the additives amounts. None of them stated the soybean protein adding. The samples were collected from the hypermarkets found in the Transylvania area and from different large-unit producers. For the positive control we have purchased the genetically modified soybean from a commercial unit.

\section{The DNA extraction}

Genomic DNA was extracted using the Isolate II genomic DNA kit (Bioline, England) according to the manufacturer's instructions. Briefly, $200 \mathrm{mg}$ of the sample was added in an Eppendorff tube and homogenized with Proteinase $\mathrm{K}$ and Lysis buffer. The samples were subjected to a high temperature for 3 hours in orther for the lysis to occur and the DNA to be released. The following steps were performed according to the kit protocol.

The PCR technique
The PCR reaction mix was performed in a volume of $25 \mu \mathrm{l}$ final reaction volume: 1X PCR green Buffer, $2.5 \mathrm{mM} \mathrm{MgCl} 2,5$ pmol of each primer, dNTPs each at $200 \mu \mathrm{M}, 2.5 \mathrm{U}$ of Taq DNA Polymerase (Bioline) and 100 ng of genomic DNA. The PCR was performed under the following conditions: $94^{\circ} \mathrm{C}$ for $3 \mathrm{~min}$ followed by 35 cycles of $94^{\circ} \mathrm{C}$ for $30 \mathrm{sec}, 56^{\circ} \mathrm{C}$ for $30 \mathrm{sec}, 72^{\circ} \mathrm{C}$ for $1 \mathrm{~min}$ and a final extension step of $72^{\circ} \mathrm{C}$ for $5 \mathrm{~min}$. The same protocol was used for both of the genes studied.

The primers used for the detection of lectine gene for normal soybean protein were previously reported by Lin et al. (2001) .For the genetically modified soybean we used the following primer sequence which amplify the EPSPS-B1 gene: Forward: TGA TGT GAT ATC TCC ACT GAC G; Reverse: TGT ATC CCT TGA GCC ATG TTG T (Lin et al., 2000).

The electrophoresis of DNA fragments

The PCR products were analyzed using a $2 \%$ agarose (CleverScientific) gel electrophoresis and the buffer used was $1 \mathrm{xTBE}$ (0.1 M Tris-HCL, 0.09 $\mathrm{M}$ boric acid and $0.001 \mathrm{M}$ EDTA). As loading dye we used RedSafe (InTron Biotechnology). The gels were electrophoresed at $80 \mathrm{~W}$ for 40 minutes in $1 \times$ TBE and reaction products viewed and recorded in a Gel Doc System (BioRad). The step was common to both of the protocols tested.

\section{RESULTS AND DISCUSSION}

Plant-derived ingredients such as soya have been in the public attention for decades due to the cheaper price in their acquisition and the properties they hold for the final products (water binding capacity, texture). The addition of undeclared soya protein in meat products is not allowed in the European Union countries due to the possible hazards that they may cause such as allergies. The undeclared adding constitutes a form of fraud which has an economic, health and regulatory impacts. Soya is considered and classified among the eight most "common allergens" including wheat, rye, cereals etc. that can cause $90 \%$ of potential fatal allergic reactions (Kurowski and Boxer, 2008).

From the total amount of samples investigated $(n=82), 5$ of them $(6.09 \%)$ were revealed to be positive for soybean lectin gene which means that soya protein was added in those products. As it can be seen in figure 1, the primers characteristic for soybean amplified a fragment of $118 \mathrm{bp}$. 
As seen in Fig. 1, 5 samples tested positive and 2 samples were amplified but in a less obvious way so we considered not to take them as positive (sample no. 1 and 9), given the probability of cross contamination during the manipulation. The reamplification of these samples (1 and 9) revealed no amplification so they were considered negative. The results of the amplification in our study proved that the primer pairs used for the determination of soya protein in admixture with meat are specific and do not generate any amplification with non-target DNA (Fig.1 and 2). For elimination of any false positive results, we used a positive control sample (DNA extracted from soybean and genetically modified soybean). Other researchers have shown that in order to have a successful PCR testing we need sufficient quality and quantity of DNA.

In the quantification of our DNA samples with the Isolate II DNA extraction kit we obtained quantity of more than $50 \mathrm{ng} / \mu \mathrm{l}$, which is an obtimum amount for PCR technique. The purities in the DNA extracted ranged from 1.8 - 2 wavelengths $260 / 280$. Also, the purities obtained reveal that the extracted DNA was not contaminated with protein or any reaction inhibitors.

For this purpose, the effects of temperature and $\mathrm{pH}$ on the integrity of DNA extracted from high temperature processed meat products, such as baloney and sausages, were extracted by using a larger quantity of lysis buffer and washing buffers. In addition, the temperature used in the extraction was prolonged at 3 hours to ensure that the membrane lysis is done properly.

The highest prevalence of soya adding without declaring on the label was noticed at baloney $(n=3)$ and sausage $(n=2)$. No positive samples were detected in the minced meat products.

After applying the PCR protocol for the detection of EPSPS-B1 gene specific to GMO soybean, we found no positive samples. Our positive control has shown an amplifyication at aproximatly 400 base pairs which is not in accordance with the weight of the fragement amplified. Although the amplified fragment is visible and no other secondary fragments revealed, we considered it to be false positive at the PCR and further sequencing requested. However, no such amplfications were observed in the case of the tested samples, being interpreted as consequence like negative samples.

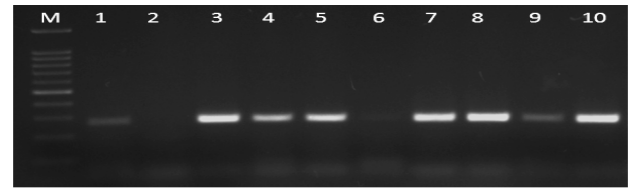

Fig.1. The electrophoretic profile of the $118 \mathrm{bp}$ fragment corresponding to soya DNA.M - ladder 100 bp (Bioline); sample 1 and 9 false positive samples; samples 2 and 6 - negative samples; samples 3,4,5,7,8 - positive samples; sample 10 - positive control (DNA extracted from soybean)

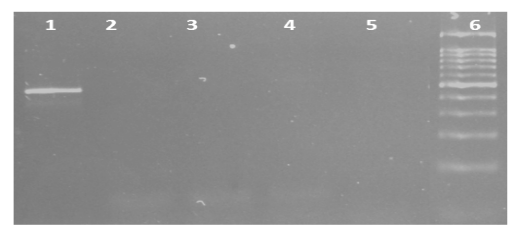

Fig. 2. The electrophoretic profile of the $418 \mathrm{bp}$ fragment corresponding to genetically modified soya DNA. Sample 1 positive control extracted from a genetically modified soybean; samples 2,3,4,5, negative samples; 6 - ladder 100 bp (Bioline)

Cawtorn et al. (2013) have revealed that the undeclared plant proteins were most prevalent in sausages, burger patties and processed meats. Similar results have been shown by Rencova and Tremlova (2009) in a study conducted on meat products marketed in Czech Republic. Our study needs to be developed further in order to be able to quantify the soya adding in the products analyzed. The shared equipments in many processing units might lead to the possibility of cross-contamination with low evels of soya which is detectable at PCR. If the soya DNA identified in the processed meat is high, leads to the possibility of intentional adding for financial gain.

\section{CONCLUSION}

Our study has shown that soya adding without declaring it on the label occurs on the regional market studied. The most prevalent products in which this adulteration occurs are the baloney and sausage products. Further researches need to be performed in order to assess the quantity added and to exclude the cross-contamination from the equipments used during the processing steps. There was no positive sample for genetically modified soya but still the low number of samples does not exclude the possibility. 


\section{REFERENCES}

1. Belloque J, Garcia MC, Torre M, Marina ML (2002). Analysis of soyabean proteins in meat products: A review. Crit Rev Food Sci Nutr 42:507-532.

2. Brandner DL (2002). PCR-Based detection of genetically modified foods. In : O'Donnell MA (Editor). Tested studies for laboratory teaching. Proceedings of the 23rd Workshop/ Conference of the Association for Biology Laboratory Education (ABLE) 23:69-84.

3. Cawthorn DM, Steinman HA, Hoffman LC (2013). A high incidence of species substitution and mislabelling detected in meat products sold in South Africa. Food Control 32: 440-449.

4. Kurowski J, Boxer RW (2008). Food allergies: detection and management. American Family Physician 77:16871688.

5. Lin HY, Chiang JW, Yang D, Shih C (2001). Detection of Genetically Modified Soybeans by PCR Method and Immunoassay Kits. Journal of Food and Drug Analysis 9(3):160-166.
6. Lin HY, Chiueh LC, Shih DYC (2000). Detection of Genetically Modified Soybeans and Maize by the Polymerase Chain Reaction Method, Journal of Food and Drug Analysis 8(3): 200-207.

7. Poms RE, Klein CL, Anklam E (2007). Methods for allergen analysis in food. Food additives and contaminants 21:131.

8. Rencová E, Tremlová B (2009). ELISA for detection of soya proteins in meat products. Acta Veterinaria BRNO 78:667671.

9. Rodriguez-Lazaro D, Lombard B, Smith H, Rzezutka A, D’Agostino M, Helmuth R (2007). Trends in analytical methodology in food safety and quality: Monitoring microorganisms and genetically modified organisms. Trends in Food Science Technology 18(6):306-319.

10. Savage JH, Kaeding AJ, Matsui EC, Wood RA (2010). The natural history of soy allergy. J Allergy Clin Immunol 125:683-6. 